\title{
A new and sensitive reaction rate method for spectrophotometric determination of trace amounts of thiourea in different water samples based on an induction period
}

\author{
Mansour Arab Chamjangali*, Gadamali Bagherian, Nasser Goudarzi and Shima Mehrjoo-Irani
}

\begin{abstract}
Background: Thiourea (TU) has various industrial, agricultural and analytical applications. TU has been labeled as having carcinogenic activity. Hypothyroidism was induced in animals by using TU. A simple and sensitive spectrophotometric reaction rate method was proposed for the determination of trace amounts of TU.

Method: The method is based on the inhibitory effect of TU on the rate of meta cresol purple (MCP) with bromate in the presence of bromide. The reaction progress was followed by monitoring the absorbance of MCP at $525 \mathrm{~nm}$.

Results: The effects of different variables on the sensitivity of the proposed method were studied and optimized. Under optimum conditions a linear relationship between induction period time and TU concentration was found in

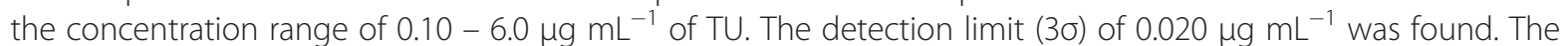
relative standard deviations for six replicate determinations of $0.10,2.0$ and $5.0 \mu \mathrm{g} \mathrm{mL}^{-1}$ of TU were $2.3 \%, 1.8 \%$ and $1.1 \%$, respectively.

Conclusion: In this study a new reaction system was proposed for the kinetic spectrophotometric determination of TU in water samples. The new method not only benefit from high selectivity and sensitivity, but also it has the advantage of fast and simple operation.
\end{abstract}

Keywords: Thiourea (TU); Kinetic; Spectrophotometry; Meta cresol purple (MCP); Induction period

\section{Background}

Thiourea (TU) has various industrial, agricultural and analytical applications. This material is widely used in photography as a fixing agent and also removes stains from negative. In agriculture, it is used as fungicides, herbicides and rodenticides (Pérez-Ruiz et al. 1995) and also to decrease the content of nitrifying bacteria in soil (Smyth and Osteryoung 1977). TU is also used for induction of early ripening in several fruits (de Oliveira et al. 2004). In analytical chemistry TU is used as a spectrophotometric reagent for determination of several metals (HE et al. 1999). TU is also used as a reagent for copper electrolytes refinery (Akeneev et al. 2005). Compounds of $\mathrm{TU}$ are often added to citrus fruits as a fungicide during

\footnotetext{
* Correspondence: marab@shahroodut.ac.ir

Department of Chemistry, Shahrood University, Shahrood, P.O. Box 36155-316,
} Iran

cold storage. TU has been labeled as having carcinogenic activity. Hypothyroidism was induced in animals by using TU (Sokkar et al. 2000; Bhide et al. 2001). Therefore, determination of $\mathrm{TU}$ at trace levels is of interest. There are some problems with determination of TU in waste water. These problems are due to the existence of a large number of organic components with relatively high concentrations, non-extractable nature of $\mathrm{TU}$ with traditional organic solvents and poor volatility of $\mathrm{TU}$, which is not easily analyzed by gas chromatography (Toyoda et al. 1979). However, various methods have been proposed for the determination of TU such as titrimetry with iodine (Amin 1985; Pillai and Indrasenan 1980) or Nbromosuccinimdie (Sarwar and Thibert 1968), Raman spectroscopy (Bowley et al. 1986), spectrophotometry (Abd El-Kader et al. 1984; Hutchinson and Boltz 1958), polarography (Trojánek and Kopanica 1985), voltammetry 
(Stará and Kopanica 1984), liquid chromatography-mass spectrometry (Xiao-Lan et al. 2009), high performance liquid chromatography (Rethmeier et al. 2001), ion selective electrode potentiometry (Radić and Komljenović 1991), FTIR (Kargosha et al. 2001), and tandem mass spectrometry (Raffaelli et al. 1997).

One of the useful methods which have been widely applied to trace determination of analytes is kinetic spectrophotometric method in which the main required equipment is a spectrophotometer. Based on the literature survey only a few numbers of indicator reactions for the kinetic determination of TU by spectrophotometric method have been published (Abbasi et al. 2009; Abbasi et al. 2010). All of these methods are based on the catalytic effect of the TU on the certain indicators reactions. To the best of our knowledge, there is no report on the use of induction period effect of TU for its kinetic determination and so this is the first report on the kinetic determination of TU based on induction period on the MCP-bromate-sulfuric acid as a novel reaction system.

In the present report a new sensitive and selective kinetic spectrophotometric method is proposed for determination of TU based on the induction period associated with TU on the catalytic oxidation of MCP by bromate. TU acts as an inhibitor on the catalytic effect of bromide ion. The reaction induction period at $525 \mathrm{~nm}$ is proportional to the TU concentration.

\section{Method}

\section{Reagents and solutions}

A $1000 \mu \mathrm{g} \mathrm{mL}^{-1}$ stock standard solution of TU was prepared by dissolving $0.1020 \mathrm{~g}$ TU (Merck) in distilled water and diluting it to $100 \mathrm{~mL}$. In order to prepare the working solutions, appropriate dilution of the stock standard solution was carried out. For preparing $0.013 \mathrm{M}$ potassium bromide solution in $100 \mathrm{~mL}$ volumetric flask, $0.1544 \mathrm{~g}$ of $\mathrm{KBr}$ (Merck) was dissolved in distilled water and diluted to the mark. A $100 \mathrm{~mL} 5.2 \times 10^{-4} \mathrm{M} \mathrm{MCP}$ solution was prepared by dissolving $0.0200 \mathrm{~g}$ of $\mathrm{MCP}$ (Merck) in $25 \mathrm{~mL}$ ethanol and diluted with distilled water in a $100 \mathrm{~mL}$ calibrated flask. In order to prepare a $100 \mathrm{~mL}$ bromate ion solution $(0.030 \mathrm{M}), 0.5010 \mathrm{~g}$ of $\mathrm{KBrO}_{3}$ (Merck) was dissolved in distielld water. Sulfuric acid solution $(0.30 \mathrm{M})$ was prepared by diluting a known volume of concentrated solution (Merck) and standardized against sodium carbonate. All reagents used in this study were of analytical grade and double distilled water was used to prepare sample solutions.

\section{Apparatus}

Absorption-time graphs at a fixed wavelength and absorption spectra were recorded on a Shimadzu UV-160 Spectrophotometer with a pair of $1.0 \mathrm{~cm}$ quartz cell. In order to control the temperature of the reaction a water bath thermostat (n-BIOTEK, INC, model NB-301) was used in this study. A stopwatch was also applied to record the time of the reactions.

\section{General procedure for determination of TU}

The reagent solutions and water were kept at $25^{\circ} \mathrm{C}$ in the thermostatic water bath for $30 \mathrm{~min}$. An appropriate volume of sample or standard solutions were transferred to a $10.0 \mathrm{~mL}$ standard flask, then $1.0 \mathrm{~mL}$ of $0.30 \mathrm{M}$ sulfuric acid, $1.0 \mathrm{~mL}$ of $5.2 \times 10^{-4} \mathrm{M} \mathrm{MCP}$ and $1.0 \mathrm{~mL}$ of $0.013 \mathrm{M}$ potassium bromide solution were added sequentially and the mixture was then diluted to ca. $8 \mathrm{~mL}$. After mixing, $1.0 \mathrm{~mL}$ of $0.030 \mathrm{M} \mathrm{KBrO}_{3}$ was added and diluted to the mark with doubly distilled water. The stopped clock was started and after transferring ca $2 \mathrm{~mL}$ of this reaction mixture to spectrophotometer cell. The change in the absorbance at $525 \mathrm{~nm}$ was recorded against water for the first 15-450 s reaction time interval. The same procedure was applied for the measurement of the blank solution (without TU). In order to construct a calibration graph reaction induction period $\left(\mathrm{t}_{\mathrm{ip}}\right)$ was plotted against TU concentration in a series of standard working solutions.

\section{Results and discussion}

MCP has been widely used in analytical chemistry in acid-base titrations, the kinetic determination of inorganic substance such as bromide (Ensafi et al. 2004a), nitrite and nitrate (Ensafi et al. 2004b) and organic analyts such as piroxicam (Arab Chamjangali et al. 2012) and phenylhydrazine (Arab Chamjangali et al. 2009). Results of experiments revealed that, the reaction rate between MCP and sodium bromate in solutions with low $\mathrm{pH}$ values at ambient temperature is not fast. When bromide ions are present in the solution, they reacts with bromate ion to produce $\mathrm{Br}_{2}$, which cause an increase in the reaction rate. A catalytic cycle is shaped when $\mathrm{MCP}$ reacts with the produced $\mathrm{Br}_{2}$ and convert to a colorless ingredient. Figure 1a shows the result of decrement in MCP absorption at $\lambda_{\max }=525 \mathrm{~nm}$ with time. It was found that TU ion has an inhibition effect on the catalytic reaction due to possible reaction with $\mathrm{Br}_{2}$ and/or bromate. Therefore, as can be seen in Figure $1 \mathrm{~b}$, in the presence of TU the reaction rate is depressed and an induction period was appeared. Further studies were carried out by recording the absorbance time profile of MCPbromate-bromide reaction system at different concentration of TU. The results (Figure 2) show that the reaction induction period, which is appeared at the initiation of the reaction, is proportional to the TU concentration.

\section{Optimization of variables}

In order to find the optimum conditions, the effects of different variables on the absorbance changes of the catalyzed $\left(\Delta \mathrm{A}_{\mathrm{c}}\right)$ and inhibited $\left(\Delta \mathrm{A}_{\mathrm{i}}\right)$ reaction were studied 

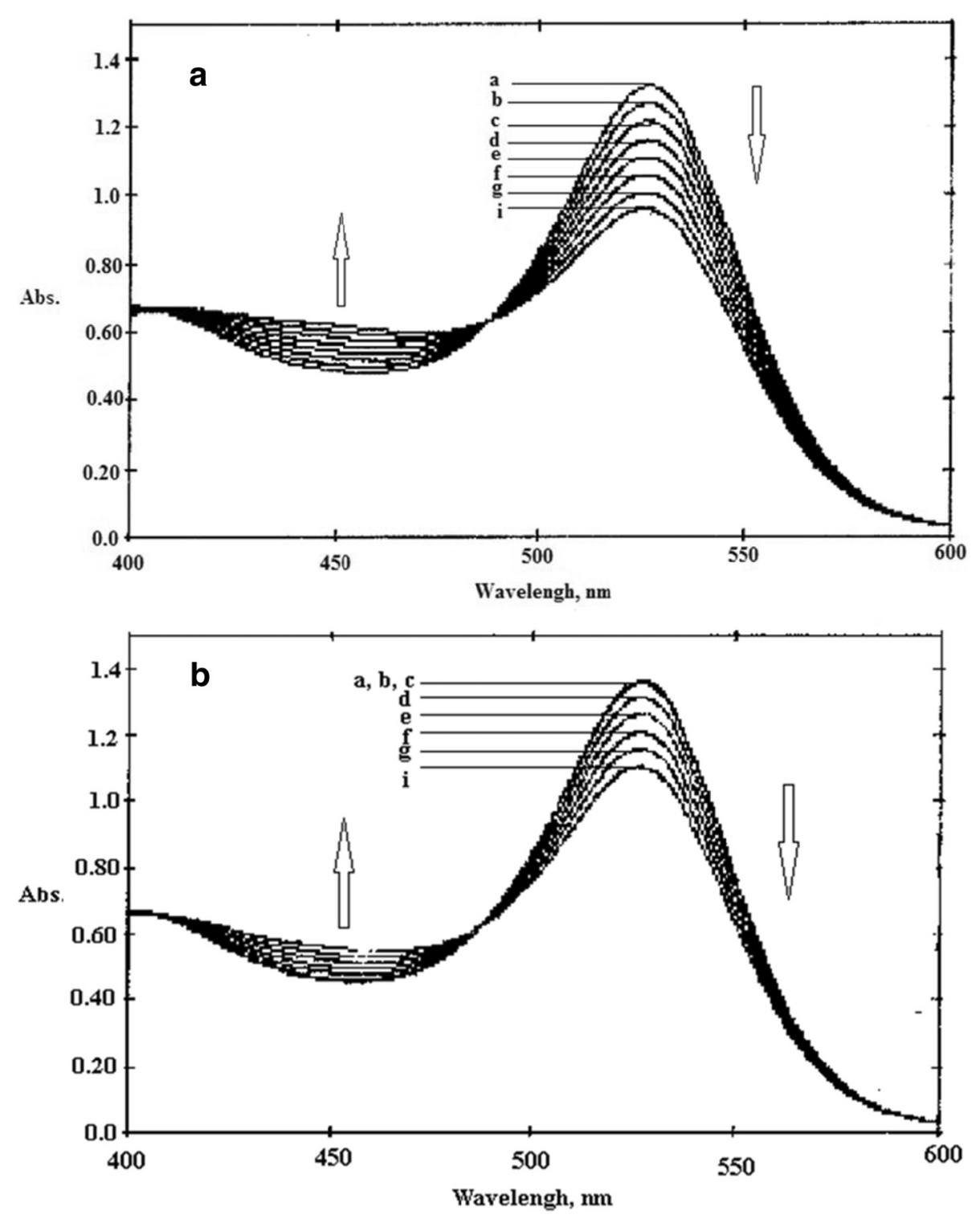

Figure 1 Absorption spectra of reaction system with scan time intervals of $30 \mathrm{~s}$ (a to i). (a) In the absence of TU and (b) in the presence of $0.50 \mu \mathrm{g} \mathrm{mL}{ }^{-1} \mathrm{TU}$. Conditions: $\mathrm{H}_{2} \mathrm{SO}_{4}, 0.030 \mathrm{M} ; \mathrm{MCP}, 5.2 \times 10^{-5} ; \mathrm{KBr}, 1.3 \times 10^{-3} \mathrm{M} ; \mathrm{KBrO}_{3}, 3.0 \times 10^{-3}$ and temperature of $25^{\circ} \mathrm{C}$.

during a fixed time of $15-115 \mathrm{~s}$. One-at-a time optimization procedure was applied in this study and the difference between absorbance changes of catalyzed and inhibited reaction $\left(\Delta \mathrm{A}=\Delta \mathrm{A}_{\mathrm{c}}-\Delta \mathrm{A}_{\mathrm{i}}\right)$ was determined and used as an analytical signal.

Based on primary studies, acidic media is the best media for observation of reaction induction period caused by TU. Thus, different acids such as sulfuric, hydrochloric and nitric acid with the same concentration were tested to find the best type of reaction medium. According to the results, sulfuric acid showed higher sensitivity. So, sulfuric acid was chosen as the best reaction medium.
In order to find out the influence of sulfuric acid concentration on the sensitivity, the effect of sulfuric acid was investigated in the concentration range of 0.010 $0.045 \mathrm{M}$. Based on the obtained results (Figure 3), $\Delta \mathrm{A}_{\mathrm{i}}$ and $\Delta \mathrm{A}_{\mathrm{c}}$ increase with increasing sulfuric acid concentration. This is due to this fact that the oxidation ability of bromate ions increases with increasing in the hydronium ion concentration. It was obvious that the maximum difference between changes in absorbance of the catalyzed and inhibited reaction was reached at $0.030 \mathrm{M}$. So, for further studies, a sulfuric acid concentration of $0.030 \mathrm{M}$, was used. 


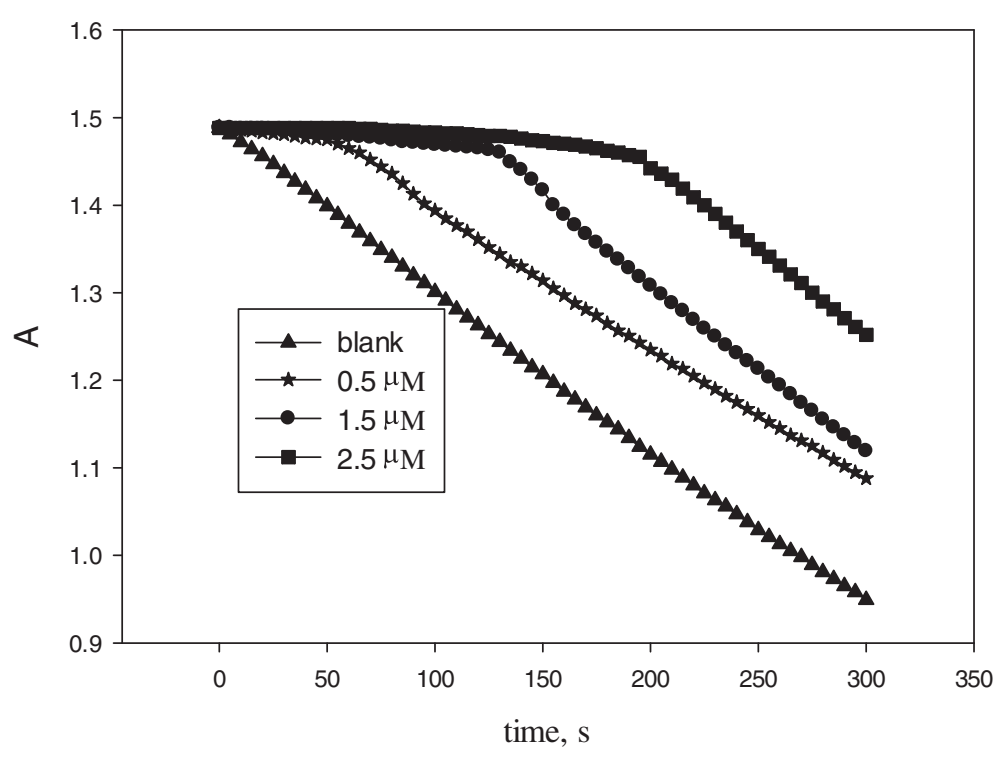

Figure 2 Absorbance-time profile. Conditions: same as Figure 1.

The dependence of sensitivity of the method on the potassium bromide concentration was studied in the range of $5.0 \times 10^{-4}$ to $2.0 \times 10^{-3} \mathrm{M}$ bromide under the optimum concentration of sulfuric acid and potassium bromate. Figure 4 reveals that both $\Delta \mathrm{A}_{\mathrm{i}}$ and $\Delta \mathrm{A}_{\mathrm{c}}$ increase with increasing $\mathrm{KBr}$ concentration and their difference $\left(\Delta \mathrm{A}_{\mathrm{c}}-\right.$ $\left.\Delta \mathrm{A}_{\mathrm{i}}\right)$ reaches its maximum value at $1.3 \times 10^{-3} \mathrm{M}$. The increases in $\Delta \mathrm{A}_{\mathrm{c}}$ and $\Delta \mathrm{A}_{\mathrm{i}}$ with increase in bromide ion concentration can be justified considering the catalytic nature of the reaction in the existence of bromide ion as the catalyst. However regarding to the obtained results, $\mathrm{KBr}$ concentration of $1.3 \times 10^{-3} \mathrm{M}$ was used as the best concentration for further studies.

The other factor which affects the analytical signal (sensitivity), is the concentration of potassium bromate (Figure 5). Result revealed that by increasing bromate concentration, $\Delta \mathrm{A}_{\mathrm{c}}$ and $\Delta \mathrm{A}_{\mathrm{i}}$ increased because of augmentation in oxidation capability of bromate with concentration. Moreover, the analytical signal and so sensitivity, increased and reached the highest value at $3.0 \times 10^{-3} \mathrm{M}$ and thus, the concentration of $3.0 \times 10^{-3}$ was used as the optimum concentration for bromate.

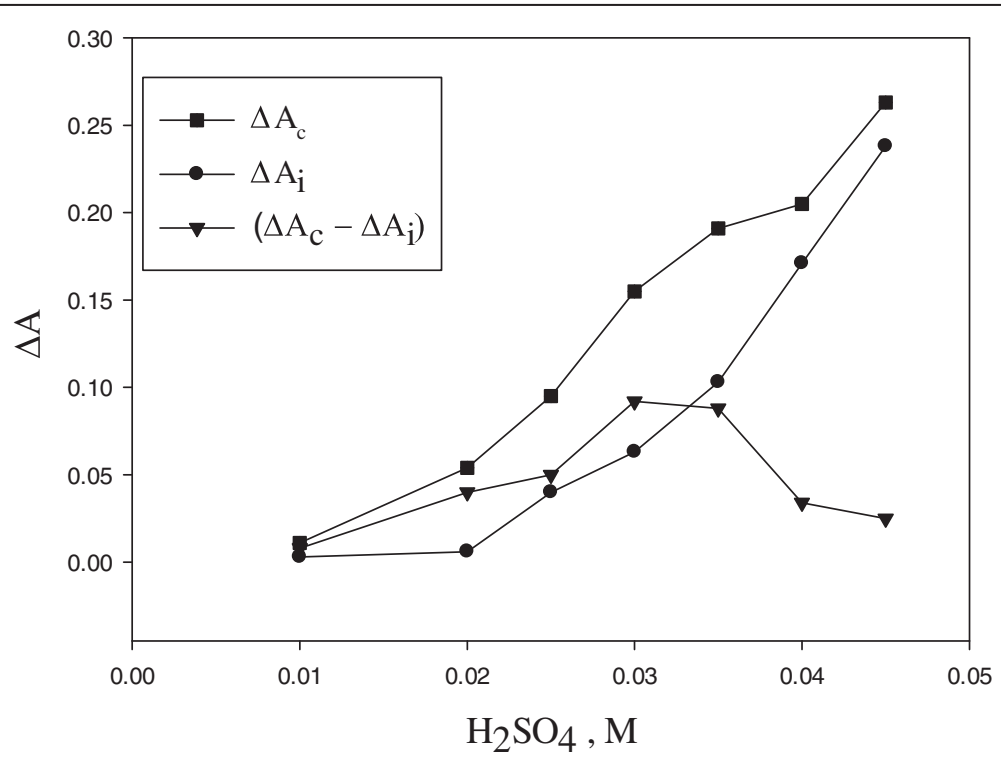

Figure 3 Effect of $\mathbf{H}_{2} \mathrm{SO}_{4}$ concentration. Conditions: $\mathrm{TU} 0.50 \mu \mathrm{g} \mathrm{mL}{ }^{-1} ; \mathrm{MCP}, 5.2 \times 10^{-5} \mathrm{M} ; \mathrm{KBr}, 1.3 \times 10^{-3} \mathrm{M}_{1} \mathrm{KBrO}_{3}, 3.0 \times 10^{-3}$ and temperature of $25^{\circ} \mathrm{C}$. 


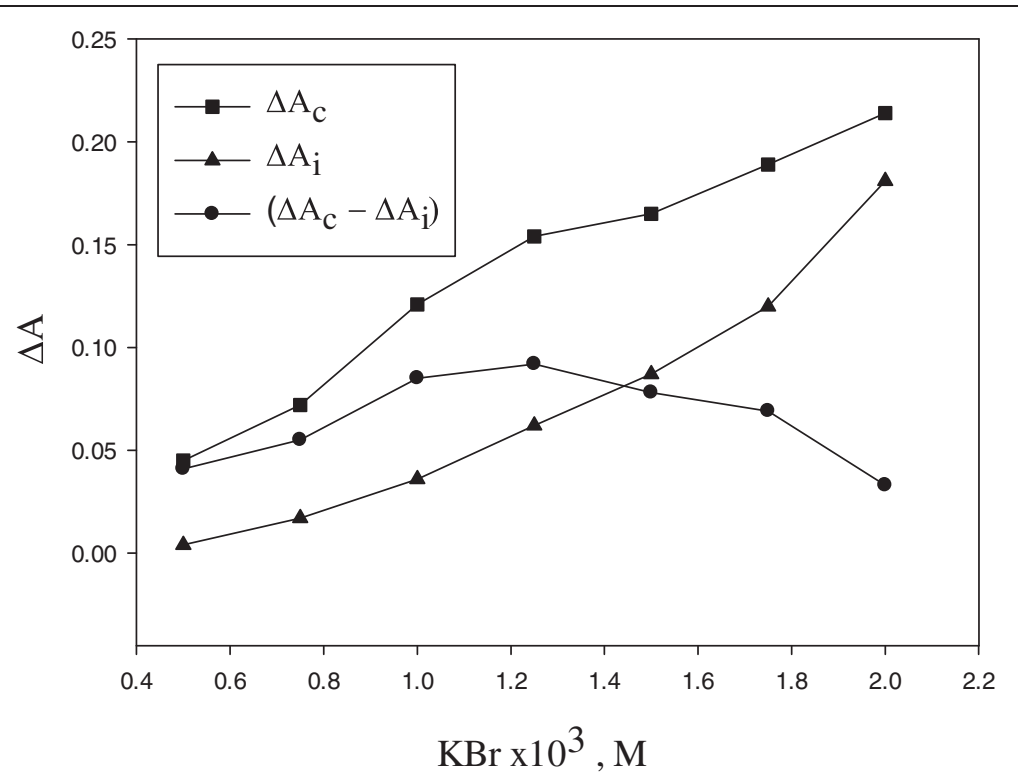

Figure 4 Effect of $\mathrm{KBr}$ concentration. Conditions: $\mathrm{TU} 0.5 .0 \mu \mathrm{g} \mathrm{mL}{ }^{-1} ; \mathrm{H}_{2} \mathrm{SO}_{4}, 0.030 \mathrm{M} ; \mathrm{MCP}, 5.2 \times 10^{-5} \mathrm{M} ; \mathrm{KBrO}_{3}, 3.0 \times 10^{-3}$ and temperature of $25^{\circ} \mathrm{C}$.

The sensitivity increased slightly as the concentration of MCP increased from $1.0 \times 10^{-5}$ to $5.7 \times 10^{-5} \mathrm{M}$ and then it deceased. For this reason, $5.2 \times 10^{-5} \mathrm{M}$ of $\mathrm{MCP}$ was selected for the recommended procedure.

The other parameter which has a severe effect on the rate of both catalyzed and inhibited reactions in this study is the temperature. So, by applying the optimized concentration of reagents, the effect of temperature was studied in the range of $5-40^{\circ} \mathrm{C}$. The results showed that the analytical signal was increased with increasing temperature. However $25^{\circ} \mathrm{C}$ (about room temperature) was used during this study.

In order to study the impact of ionic strength on the reaction induction period (analytical signal used in construction calibration curve) potassium nitrate $(2.0 \mathrm{M})$ was used under the aforementioned optimum values.

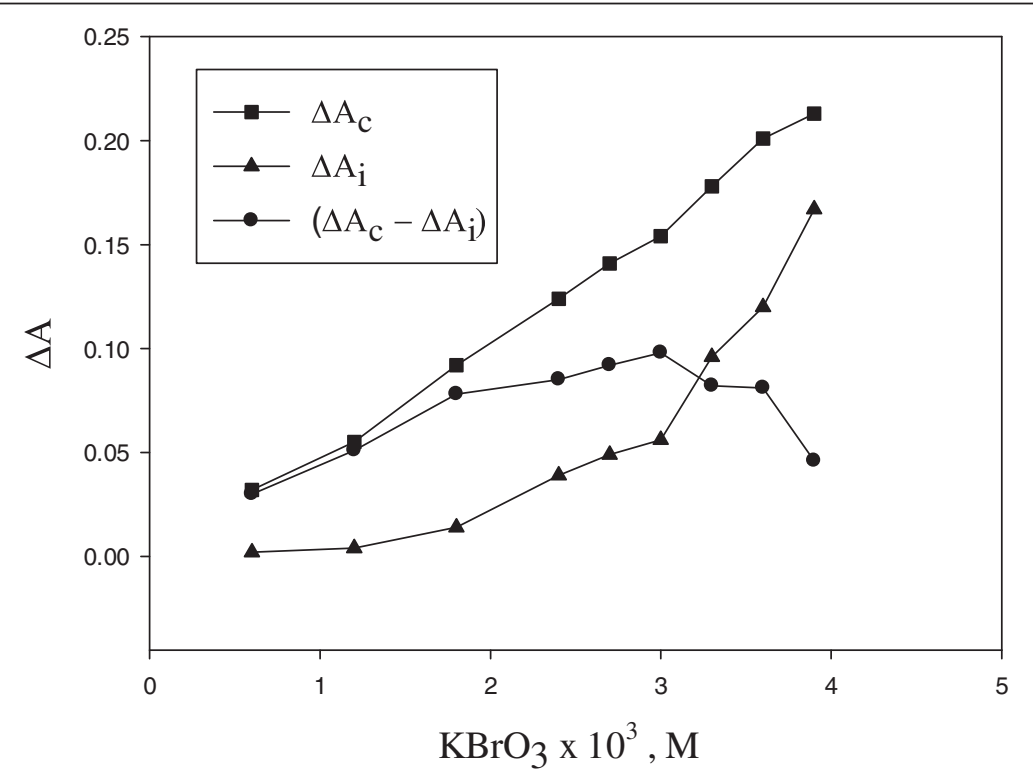

Figure 5 Effect of $\mathrm{KBrO}_{3}$ concentration. Conditions: $\mathrm{TU} 0.50 \mu \mathrm{g} \mathrm{mL}{ }^{-1} ; \mathrm{H}_{2} \mathrm{SO}_{4}, 0.030 \mathrm{M} ; \mathrm{MCP}, 5.2 \times 10^{-5} \mathrm{M} ; \mathrm{KBr}, 1.30 \times 10^{-3} \mathrm{M}$ and temperature of $25^{\circ} \mathrm{C}$. 
Table 1 Interferences for the determination of TU $\left(0.50 \mu \mathrm{g} \mathrm{mL}^{-1}\right)$

\begin{tabular}{|c|c|}
\hline Species & $\begin{array}{l}\text { Tolerance limit } \\
\left(\mathrm{W}_{\text {Species }} / \mathrm{W}_{\text {TU }}\right)\end{array}$ \\
\hline $\mathrm{Co}^{+2}, \mathrm{Na}^{+}, \mathrm{Ca}^{+2}, \mathrm{Al}^{+3}, \mathrm{~K}^{+}, \mathrm{NO}_{3}{ }^{-}, \mathrm{S}_{2} \mathrm{O}_{8}^{-2}$, Urea, Glucose & 1000 \\
\hline $\mathrm{Cu}^{+2}$ & 800 \\
\hline $\mathrm{Cd}^{+2}, \mathrm{Zn}^{+2}, \mathrm{Mn}^{+2}, \mathrm{Mg}^{+2}, \mathrm{Fe}^{+3}$ & 500 \\
\hline Citrate, Acetate, $\mathrm{Ba}^{+2}$ & 300 \\
\hline EDTA, $\mathrm{Pb}^{+2}$, Oxalate & 200 \\
\hline Formate, Salicylate, $\mathrm{PO}_{4}{ }^{3-}$ & 100 \\
\hline $\mathrm{CO}_{3}^{2-}$ & 80 \\
\hline $\mathrm{CN}^{-}$ & 65 \\
\hline $\mathrm{Ni}^{+2}$ & 40 \\
\hline $\mathrm{Cl}^{-}$, Tartaric acid & 20 \\
\hline $\mathrm{Cr}_{2} \mathrm{O}_{7}^{2-}, \mathrm{Ag}^{+}$ & 5 \\
\hline $\mathrm{Hg}^{+2}$ & 2 \\
\hline
\end{tabular}

Based on the obtained results, the induction period was not affected by the ionic strength up to $0.32 \mathrm{M}$ (maximum value tested) of sodium nitrate.

\section{Selectivity}

The effect of some foreign species on the determination of $0.50 \mu \mathrm{g} \mathrm{mL}^{-1} \mathrm{TU}$ were examined. The extreme tolerable concentration was taken as a concentration of foreign species that produce a change in the induction period more than $\pm 5 \%$. Table 1 shows the achieved results. Most cations and anions did not interfere even if they were present in amounts of 1000-fold greater than TU. The inhibitory effect of $\mathrm{Hg}^{2+}$ was observed. The interference effect of mercury (II) ion was decreased (up to 150-fold) by precipitation using $0.010 \mathrm{M}$ sodium hydroxide solution. The results (Table 1) demonstrate that this method has good selectivity.

\section{Calibration and analytical parameters}

The optimum condition of $0.030 \mathrm{M}$ sulfuric acid, $3.0 \times$ $10^{-3} \mathrm{M}$ potassium bromate, $1.3 \times 10^{-3} \mathrm{M}$ potassium bromide, and $5.2 \times 10^{-5} \mathrm{M} \mathrm{MCP}$ at a temperature of $25^{\circ} \mathrm{C}$ was applied to plot a calibration graph. The reaction induction period under optimum condition was linear to TU concentration in the ranges of $0.10-6.0 \mu \mathrm{g} \mathrm{mL}{ }^{-1}$ with a regression equation of $t_{i p}=67.1( \pm 0.6) C_{T U}+20.7$ $( \pm 0.5)(\mathrm{r}=0.9990, \mathrm{n}=14)$. Where, $\mathrm{C}_{\mathrm{TU}}$ is the TU concentration in $\mu \mathrm{g} \mathrm{mL}^{-1}$ and $t_{i p}$ is the reaction induction period in seconds. The induction period was measured by extrapolation as illustrated in Figure 6.

The experimental $3 \sigma$ detection limit is $20 \mathrm{ng} \mathrm{mL}{ }^{-1}$. For investigation of the accuracy and precision of the proposed method, standard solutions of 0.10, 2.0 and $5.0 \mu \mathrm{g} \mathrm{mL} \mathrm{m}^{-1}$ of $\mathrm{TU}$ were studied using suggested

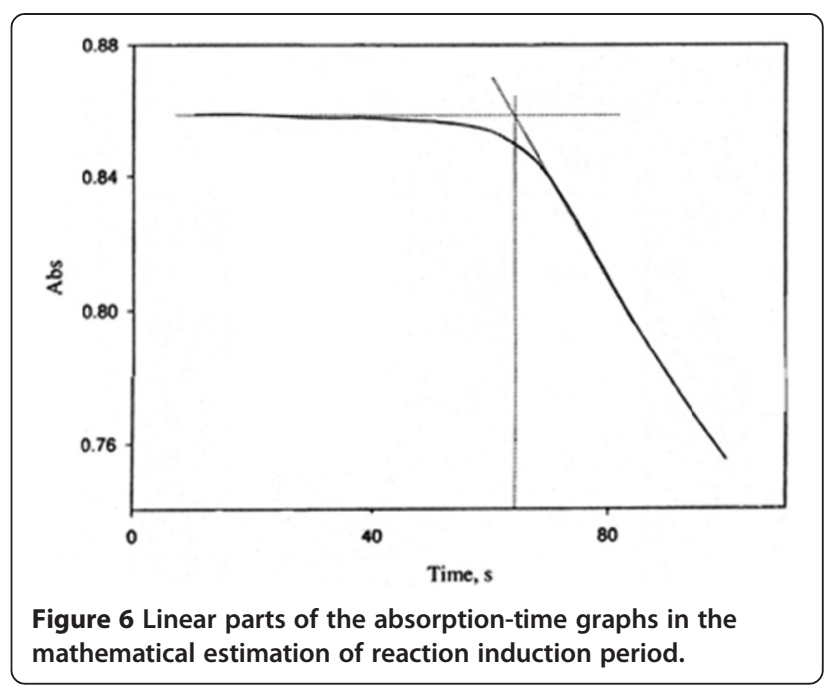

procedure. Each concentration was tested six times and the relative standard deviations (RSD) of $2.3 \%, 1.8 \%$ and $1.1 \%$ were achieved respectively. The analytical parameters of reported methods for determination of TU are summarized in Table 2. It was clear that the detection limit of the proposed method is better than or comparable with othe reported methods (Toyoda et al. 1979, Abbasi et al. 2009). Some of these methods have better detection limit than the proposed method (Abbasi et al. 2010, Raffaelli et al. 1997), but suffer from the expensive equipments (Raffaelli et al. 1997)or time consuming (Abbasi et al. 2010).

\section{Real sample analysis}

The proposed method was effectively used for analysis of different spiked water samples (mineral and springer water). In analysis of water samples the procedure described in the experimental section was applied and the

Table 2 The analytical parameters of reported methods for determination of TU

\begin{tabular}{lllll}
\hline No & Method & $\begin{array}{l}\text { Linear range } \\
\left(\boldsymbol{\mu} \mathbf{~ m L}^{-\mathbf{1}}\right)\end{array}$ & $\begin{array}{l}\text { Detection } \\
\text { limit } \\
\left(\boldsymbol{\mu g} \mathbf{~ m L}^{-\mathbf{1}}\right)\end{array}$ & Ref \\
\hline $1 \quad \begin{array}{l}\text { Gas-liquid } \\
\text { chromatography }\end{array}$ & NR & 0.08 & $\begin{array}{l}\text { Toyoda et al. } \\
1979\end{array}$ \\
$2 \quad \begin{array}{l}\text { Kinetic catalytic } \\
\text { spectrophotometry }\end{array}$ & $0.03-10$ & 0.02 & $\begin{array}{l}\text { Abbasi et al. } \\
2009\end{array}$ \\
$3 \quad \begin{array}{l}\text { Kinetic catalytic } \\
\text { spectrophotometry }\end{array}$ & $0.01-12$ & 0.008 & $\begin{array}{l}\text { Abbasi et al. } \\
2010\end{array}$ \\
$4 \quad \begin{array}{l}\text { Tandem Mass } \\
\text { Spectrometry }\end{array}$ & $0.01-5.0$ & 0.001 & $\begin{array}{l}\text { Raffaelli et al. } \\
1997\end{array}$ \\
5 & $\begin{array}{l}\text { Kinetic induction base } \\
\text { spectrophotometry }\end{array}$ & $0.10-6.0$ & 0.02 & This work \\
\hline
\end{tabular}




\begin{tabular}{|c|c|c|c|c|}
\hline Sample & $\begin{array}{l}\text { Add } \\
\left(\mu \mathrm{g} \mathrm{mL}^{-1}\right)\end{array}$ & $\begin{array}{l}\text { Found } \\
\left(\mu \mathrm{gL}^{-1}\right)\end{array}$ & Recovery\% & $\begin{array}{l}\text { RSD } \% \\
(n=3) \\
\end{array}$ \\
\hline \multirow[t]{5}{*}{ Abshar Spring } & ---- & ND & ----- & ---- \\
\hline & 0.40 & 0.41 & 102 & 1.7 \\
\hline & 1.00 & 1.06 & 106 & 2.1 \\
\hline & 2.00 & 2.03 & 102 & 2.4 \\
\hline & 5.50 & 5.47 & 99 & 1.3 \\
\hline \multirow[t]{6}{*}{ Mireral Water } & ---- & ND & ----- & ---- \\
\hline & 0.20 & 0.21 & 105 & 1.6 \\
\hline & 0.50 & 0.52 & 104 & 2.9 \\
\hline & 1.50 & 1.52 & 101 & 2.2 \\
\hline & 3.00 & 3.01 & 101 & 2.3 \\
\hline & 5.00 & 5.03 & 101 & 1.8 \\
\hline
\end{tabular}

concentration of TU was calculated using constructed calibration graph. The results are shown in Table 3. The validity of the proposed method in the analysis of real samples is evident from the calculated recoveries. The student's t- test at 95\% confidence level did not show any systematic error in the proposed method and thus confirms its reliability.

\section{Conclusions}

In this study a new reaction system was proposed for the kinetic spectrophotometric determination of TU in water samples. The new method not only benefit from high selectivity and sensitivity, but also it has the advantage of fast and simple operation. Besides, using cheap reagents and simple instrumentations in which minimum maintenance is required are the other reasons for favorably of the proposed method.

\section{Competing interests}

The authors declare that they have no competing interests.

\section{Authors' contributions}

All authors read and approved the final manuscript.

\section{Acknowledgment}

The authors are thankful to the Shahrood University Research Council for the support of this work

Received: 30 November 2014 Accepted: 10 February 2015

Published online: 04 March 2015

\section{References}

Abbasi S, Khani H, Gholivand MB, Naghipour A, Farmany A, Abbasi F (2009) ) A kinetic method for the determination of thiourea by its catalytic effect in micellar media. Spectrochim. Acta. Adv Physiol Educ 72:327-331

Abbasi S, Khani H, Hosseinzadeh L, Safari Z (2010) Determination of thiourea in fruit juice by a kinetic spectrophotometric method. J Hazard Mater 174:257-262

Abd El-Kader AK, Ahmed YZ, El-mottalb MA (1984) Spectrophotometric determination of thiosulfate, thiocyanate and thiourea ions by using sodium Nitroprusside as a complexing agent. Anal Lett 17:2259-2266
Akeneev YA, Zakharova EA, Slepchenko GB, Pikula NP (2005) Voltammetric determination of thiourea in copper refinery electrolytes. J Anal Chem 60:514-517

Amin D (1985) Determination of thiourea, phenylthiourea and allythiourea with iodine. Analyst 110:215-216

Arab Chamjangali M, Bagherian G, Ameri S (2009) A new induction period based reaction rate method for determination trace amounts of phenylhydrazine in water samples. J Hazard Mater 166:701-705

Arab Chamjangali M, Bagherian G, Mehrjoo-Irani S (2012) Determination of Piroxicam in different pharmaceutical products by a simple kinetic procedure based on an induction period effect. Anal Chem Lett 2:44-55

Bhide SV, Deshmukh BT, Talvelkar BA, Nagvekar AS (2001) Effect of induced hypothyroidism on the blood biochemical constituents in goats. Indian Vet J 78:205-208

Bowley HJ, Crathorne EA, Gerrard DL (1986) Quantitative determination of thiourea in aqueous solution in the presence of sulphur dioxide by Raman spectroscopy. Analyst 111:539-542

de Oliveira AN, de Santana H, Zaia CTBV, Zaia DAM (2004) A study of reaction between quinones and thiourea: determination of thiourea in orange juice. J Food Comp Anal 17:165-177

Ensafi AA, Rezaei B, Nouroozi S (2004a) Highly selective spectrophotometric flow-injection determination of trace amounts of bromide by catalytic effect on the oxidation of m-cresolsulfonephthalein by periodate. Spectrochim. Acta. Adv Physiol Educ 60:2053-2057

Ensafi AA, Rezaei B, Nouroozi S (2004b) Simultaneous spectrophotometric determination of nitrite and nitrate by flow injection analysis. Anal Sc 20:1749-1753

HE Z, WU F, MENG H, LING L, YUAN L, LUO Q, ZENG Y (1999) Chemiluminescence determination of thiourea using tris (2, 2'-bipyridyl) ruthenium (II)- $\mathrm{KMnO}_{4}$ system. Anal Sci 15:381-383

Hutchinson K, Boltz DF (1958) Spectrophotometric determination of nitrite and thiourea. Anal Chem 30:54-56

Kargosha K, Khanmohammadi M, Ghadiri M (2001) Fourier transform infrared spectrometric determination of thiourea in the presence of sulphur dioxide in aqueous solution. Anal Chim Acta 437:139-143

Pérez-Ruiz T, Martínez-Lozano C, Tomás V, Casajús R (1995) Flow injection fluorimetric determination of thiourea. Talanta 42:391-394

Pillai CPK, Indrasenan P (1980) lodamine-T as an oxidemetric titrant in aqueous medium. Talanta 27:751-753

Radić N, Komljenović J (1991) Potentiometric determination of mercury(II) and thiourea in strong acid solution using an ion-selective electrode with Agl-based membrane hydrophobised by PTFE. Fresenius J Anal Chem 341:592-596

Raffaelli A, Pucci S, Lazzaroni R, Salvadori P (1997) Rapid determination of thiourea in waste water by atmospheric pressure chemical ionization tandem mass spectrometry using selected-reaction monitoring. Rapid Commun Mass Spectrom 11:259-264

Rethmeier J, Neumann G, Stumpf C, Rabenstein A, Vogt C (2001) Determination of low thiourea concentrations in industrial process water and natural samples using reversed-phase high-performance liquid chromatography. J Chromatogr A 934:129-134

Sarwar M, Thibert RJ (1968) Titrimetric determination of thiourea and thioacetamide using N-bromosuccinimide. Anal Lett 1:381-384

Smyth MR, Osteryoung JG (1977) Determination of some thiourea-containing pesticides by pulse voltammetric methods of analysis. Anal Chem 49:2310-2314

Sokkar SM, Soror AH, Ahmed YF, Ezzo OH, Hamouda MA (2000) Pathological and biochemical studies on experimental hypothyroidism in growing lambs. J. Vet. Med., Ser. Biogeosciences 47:641-652

Stará V, Kopanica M (1984) Adsorptive stripping voltammetric determination of thiourea and thiourea derivatives. Anal Chim Acta 159:105-110

Toyoda M, Ogawa S, Ito Y, Iwaida M (1979) Gas-liquid chromatographic determination of thiourea in citrus peels. J Assoc Off Anal Chem 62:1146-1149

Trojánek A, Kopanica M (1985) Thin-layer polarographic detector for the high-performance liquid chromatographic detection of thiourea derivatives. J Chromatogr A 328:127-133

Xiao-Lan H, Hui-Tai L, Hui-Qin W, Wen-Rui C, Zhi-Fei Z, Fang H, Xiao-Shan L, Zhi-Xin Z (2009) Determination of thiourea in noodle and rice flour by liquid chromatography-mass spectrometry. Chinese J Anal Chem 37:1531-1534 